\title{
Pharmaceutical Waste Water Treatment \& Related Economic Aspects for Reuse in the Context of Bangladesh
}

\author{
Sadia Afreen ${ }^{1}$, Smita Paul ${ }^{2}$ \\ ${ }^{1}$ Engineering Officer (Chemical), Dhaka Plant, Essential Drugs Co. Ltd, Email: sadiafreen002@gmail.com \\ ${ }^{2}$ Planning Director, Eye Stopper Ltd, Dhaka
}

\begin{abstract}
The purpose of the work is to investigate the scenario of waste water treatment in pharmaceutical industries in Bangladesh and find some advanced steps to add in the existing ETP with economic considerations. For this, a renowned pharmaceutical industry in Bangladesh has been chosen that represents the feature of ETP in Bangladesh. Generally industries, including pharmaceuticals, discharge their waste water to the environment after treatment; the objective is to show some beneficial ways to use/reuse the treated water, applicable for the pharmaceutical industries in Bangladesh. Sample has been provided by ACI Pharmaceuticals Ltd. and different parameters of their supplied samples (both from inlet and outlet) have been measured to check whether they suit with the present standards of drinking water and/or other standards of industrial discharged water in context of Bangladesh. From the experiment it is found that the values of the different parameters of the treated water of the chosen industry can be considered to be favorable in comparison with the present standards of waste water regulations in Bangladesh. The present investigation also shows that if an ion exchange unit or membrane separation technology is incorporated after filtration, the waste water can be made potable after treatment by implementing some advanced technology.
\end{abstract}

\section{INTRODUCTION}

Water is said to be "the matrix of our life". In every sphere of our day-to-day life water plays its role without which we just cannot imagine life itself. The interesting part is most of the huge needs for pure water and its uses cause pure water to be contaminated, which creates a vicious circle. This vicious circle of water crisis is again backed by population increase, as these two are inversely proportional. This is an alarming concern now since of the total water amount $2.5 \%$ is fresh water and only $1 \%$ is accessible [1]. This small amount of pure water along with the wastage and so many uses has led a scarce situation already for the availability of pure water. Under the current situation we are not supposed to depend further on natural source of water. And the solution is to reuse the water. In this work the necessity and feasibility of water treatment of Pharmaceutical industries in Bangladesh have been examined and investigated. Pharmaceutical industries incorporate a number of chemicals both soluble and insoluble in water. The residue water is drained out being polluted with those chemicals in suspended, colloidal, dissolved solidsmineral, organic toxic form and harms the environment. The contamination resulted from the pharmaceutical waste water are odor, synthetic drugs contain $\mathrm{CN}$, and high BOD. From 1999 to 2002, the United States Geologic Survey (USGS) studied surface and groundwater samples from around the country to determine whether PPCPs were present. They found at least one compound in $80 \%$ of streams and $93 \%$ of groundwater [1]. In Bangladesh there are a good number of pharmaceutical industries and they are discharging their waste water regularly to the environment. Many of them are situated by rivers, lakes or near other water resources, some are near residential area. Some of them use ETP and some do not for the purpose of saving cost which is actually a threatening condition for the health of environment in Bangladesh. Industries that are using ETP generally discharge the water at nearby water resources after the treatment of waste water. To investigate the scenario of their treatment the sample water from ACI pharmaceutical has been collected. All data used in this work are based on the supplied reports and investigation in 2007 [2]. After the sample collection, different parameters of water have been examined before and after the treatment of waste water. The values of the parameters have been compared to that of the standards in Bangladesh. Additionally, some different ways of reusing the treated water have been proposed here which can lessen the burden of using pure water in many sectors.

\section{SAMPLE METHODOLOGY}

For the purpose of measuring the condition of waste water before and after the treatment, sample water was collected from ACI Ltd, which is a top ranked pharmaceutical of the country, producing number of products relating to human health. Sample has been provided by the ACI Pharmaceutical Industry from its Narayanganj Plant which is situated by the bank of Shitalakkha River. The sample water was collected from three points:

-From inlet which is actually pure ground water. -From outlet, the effluent water without treatment. -From ETP outlet, the water after treatment 


\section{PROCEDURE OF EXPERIMENT}

Standard analytical methods have been used for measuring all the required parameters of waste water.

\section{EQUIPMENTS}

Along with the auxiliary equipments for the experiments to check the water parameters and quality, two additional major equipments have been used regularly.

\section{Spectrophotometer, HACH Dr/4000}

2. Denver Instrument, Model-215.

\section{DIFFERENT ION CONCENTRATION}

Besides the measurement of common parameters of waste water, different metallic and non metallic ion concentration were measured for the complete qualitative analysis of the raw water. The Hach Model $D R / 4000$ was used for this purpose. The procedures for these tests are given in details in the HACH manual book. Some of the parameters are directly related to inorganic toxicity of the wastewater.

\section{RESULT AND DISCUSSION}

Different parameters of the wastewater and laboratory treated potable water are compared to verify the effectiveness of the treatment procedure. Experimental observations are presented in the following table. Due to the unavailability of proper facility and appropriate equipments some parameters' test was not conducted completely during the experiment. Those parameters are presented in the table with blank expression. The qualitative water parameters were evaluated both for the raw waste water and laboratory treated water. The measured physical and chemical parameters for the treated water are compared with the standard water to check out the accuracy of treatment procedure as well as the feasibility to make the treated water potable. From the experimental result it is shown that the BOD and COD value after the treatment of waste water can be much favorable compared to that of Bangladesh standards. The value of TDS and other ion concentration found after the treatment of waste water is also favorable which indicates the scope of using this water again in some other purpose or propose some ways to get benefits economically from reusing it.
Table1. Comparison of water treatment result

\begin{tabular}{|c|c|c|c|c|c|}
\hline \multirow[t]{2}{*}{ Parameter } & \multirow[t]{2}{*}{ Unit } & \multirow{2}{*}{$\begin{array}{c}\text { WHO } \\
\text { Potable } \\
\text { Stan- } \\
\text { dards }\end{array}$} & \multirow{2}{*}{$\begin{array}{c}\text { Bangladesh } \\
\text { Standards } \\
\text { for } \\
\text { Drinking } \\
\text { Water }\end{array}$} & \multicolumn{2}{|c|}{$\begin{array}{l}\text { Sample } \\
\text { Result }\end{array}$} \\
\hline & & & & $\begin{array}{l}\text { Be- } \\
\text { fore }\end{array}$ & After \\
\hline $\mathrm{pH}$ & & $6.5-9.2$ & $6.5-.8 .5$ & 7.2 & 7.51 \\
\hline Arsenic & $\mathrm{mg} / \mathrm{L}$ & 0.05 & 0.05 & $<10$ & trace \\
\hline Ammonia & $\mathrm{mg} / \mathrm{L}$ & 5 & 0.5 & 2.9 & 0.236 \\
\hline BOD & $\mathrm{mg} / \mathrm{L}$ & 6.0 & 0.2 & 282 & 2 \\
\hline $\mathrm{COD}$ & $\mathrm{mg} / \mathrm{L}$ & - & 4 & 449 & 4.2 \\
\hline Magnesium & $\mathrm{mg} / \mathrm{L}$ & 30 & $30-35$ & 0.01 & 0.01 \\
\hline Lead & $\mathrm{mg} / \mathrm{L}$ & 0.1 & 0.05 & 0.031 & 0.012 \\
\hline Barium & $\mathrm{mg} / \mathrm{L}$ & 0.7 & 0.10 & 560 & 0.68 \\
\hline TS & $\mathrm{mg} / \mathrm{L}$ & - & - & 2016 & 226 \\
\hline TDS & $\mathrm{mg} / \mathrm{L}$ & 500 & 1000 & 1100 & 208 \\
\hline TSS & $\mathrm{mg} / \mathrm{L}$ & - & - & 38 & 5 \\
\hline Turbidity & JTU & 10 & 10 & 5 & 2.5 \\
\hline Chromium & $\mathrm{mg} / \mathrm{L}$ & 0.05 & 0.05 & 3.2 & 0.01 \\
\hline Cyanide & $\mathrm{mg} / \mathrm{L}$ & 0.05 & 0.1 & 0.6 & 0.009 \\
\hline Chloride & $\mathrm{mg} / \mathrm{L}$ & $150-600$ & $150-600$ & 27.5 & 6.58 \\
\hline Nitrate & $\mathrm{mg} / \mathrm{L}$ & 4.5 & 10 & - & - \\
\hline Color & & 15 & 15 & Black & Clear \\
\hline
\end{tabular}

\section{EXISTING ETP OF ACI}

The following is the existing ETP of ACI Ltd. which also represents the waste water treatment procedure followed more or less by other pharmaceutical industries in Bangladesh.

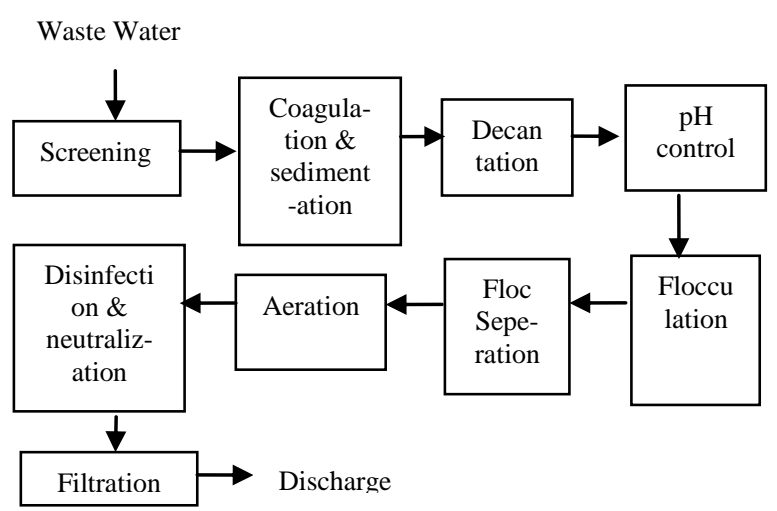

Fig. 1: Schematic diagram of ETP of ACI ltd

\section{RECOMMENDED ETP}

Like other pharmaceutical industries, ACI discharges its effluent to the environment after it gets treated up to the Standards of Industrial Waste Removal, Bangladesh; but incorporating some advanced steps to their ETP can offer an exclusive feature to the industries like this. 


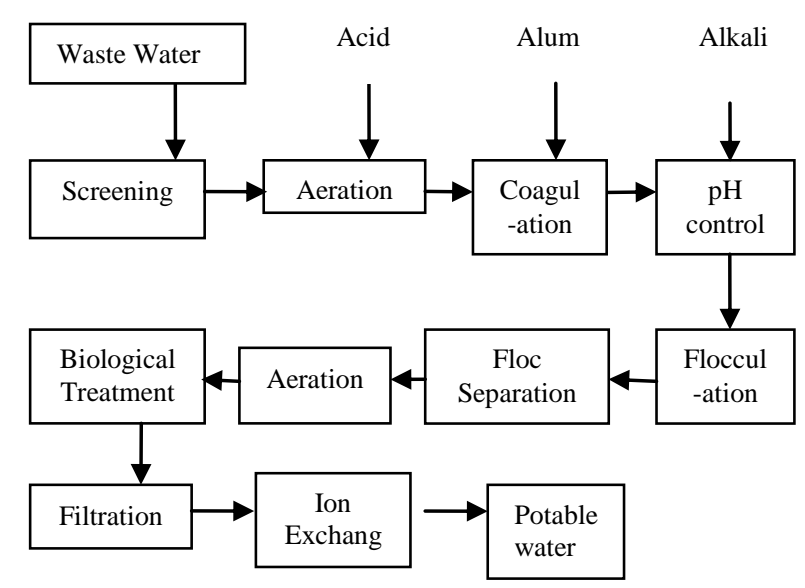

Fig. 2: Schematic Diagram of Proposed ETP

The treatment procedure consists of the regular steps to treat the waste water; but some additional steps have been recommended here for the purpose of making it potable. The treatment procedure is described here on the basis of $250 \mathrm{ml}$ of waste water.

- $250 \mathrm{ml}$ wastewater is taken in a beaker from sample wastewater.

- Screening of the sample is carried by filter.

- Its $\mathrm{pH}$ is controlled to 8 with the addition of $98 \%$ commercial grade $\mathrm{H}_{2} \mathrm{SO}_{4}$ and simultaneous aeration is carried out. In the aeration unit air is supplied with a PVC pipe connected to a pump.

- $12.5 \mathrm{gm}$ alum is added to this solution as coagulant agent. Separation of solid is observed.

- Addition of alum decreases the $\mathrm{P}^{\mathrm{H}}$. So $50 \% \mathrm{NAOH}$ solution is added to rise $\mathrm{P}^{\mathrm{H}}$ to 6.5

- $0.05 \%$ Polyelectrolyte solution is then added to the solution as flocculating agent. The flocs are formed at bottom

- After floc removal the sample is fit for biological treatment. Aeration is carried out with a PVC pipe connected to a pump.

- After aeration $0.25 \mathrm{gm}$ urea food grade phosphoric acid and a commercial nutrient Han Bio is added to the aerated water.

- Then it is filtered again in 9 bed sand filter.

- Then the filtrate is passed through an ion exchange resin bed consisting cationic and anionic resins in the 2:1 ratio. It is passed by bed 5 times and passing demineralised water regenerates the bed (Recommended).

\section{ECONOMIC CONSIDERATIONS FROM ASPECTS OF BANGLADESH}

The following table shows the comparison between the existing ETP and the proposed one in this work. Calculations have been made on the basis of standard assumptions \& procedures.
Table 2. Comparison of ACI economy [2]

\begin{tabular}{|c|c|c|}
\hline Article & $\begin{array}{c}\text { ACI } \\
\text { Economy } \\
\text { (with } \\
\text { existing } \\
\text { ETP) tk }\end{array}$ & $\begin{array}{c}\text { ACI Economy } \\
\text { (with proposed ETP) } \\
\text { tk }\end{array}$ \\
\hline Capital cost & $66.17 \times 10^{7}$ & $66.52 \times 10^{7}$ \\
\hline $\begin{array}{c}\text { Other } \\
\text { expenses }\end{array}$ & $1.75 \times 10^{9}$ & $1.783 \times 10^{9}$ \\
\hline $\begin{array}{c}\text { Total turnover } \\
\text { Profit as } \\
\text { turnover } \\
\text { percentage }\end{array}$ & $3.165 \%$ & $16.10 \%$ \\
\hline $\begin{array}{c}\text { Incremental } \\
\text { profit } \\
\text { percentage }\end{array}$ & - & $43.79 \%$ \\
\hline Payout period & - & $1.13 \mathrm{yrs}$ \\
\hline
\end{tabular}

\section{REUSING THE TREATED WATER IN OTHER BENEFICIAL WAYS}

Considering the economic evaluation, industries can be reluctant to set up new ETP with a view to treating the water up to potable grade. In such case, some alternative ways can be proposed to reuse the water that is treated out from the existing ETP. The following table shows the different parameters value of waste water and their standards in different applications in context of Bangladesh.

Table 3: Comparison of water standards among the treated water and water discharged in different places

\begin{tabular}{|c|c|c|c|c|c|}
\hline \multirow[t]{2}{*}{ Parameters } & \multirow[t]{2}{*}{ Unit } & \multicolumn{2}{|c|}{ Sample Result } & \multirow{2}{*}{$\begin{array}{c}\text { Inland } \\
\text { Surface } \\
\text { water }\end{array}$} & \multirow{2}{*}{$\begin{array}{c}\text { Irrigated } \\
\text { Land }\end{array}$} \\
\hline & & $\begin{array}{c}\text { Before } \\
\text { Treatment }\end{array}$ & $\begin{array}{c}\text { After } \\
\text { Treatment }\end{array}$ & & \\
\hline $\mathrm{PH}$ & & 7.2 & 7.51 & $6-9$ & $6-9$ \\
\hline Arsenic & $\mathrm{mg} / \mathrm{l}$ & $<10$ & Trace & 0.2 & 0.2 \\
\hline Ammonia & $\mathrm{mg} / \mathrm{l}$ & 2.9 & 0.236 & 5 & 15 \\
\hline BOD & $\mathrm{mg} / \mathrm{l}$ & 282 & 2 & 50 & 100 \\
\hline COD & $\mathrm{mg} / \mathrm{l}$ & 449 & 4.2 & 200 & 400 \\
\hline Magnesium & $\mathrm{mg} / \mathrm{l}$ & 0.01 & 0.01 & - & - \\
\hline Lead & $\mathrm{mg} / \mathrm{l}$ & 0.031 & 0.012 & 0.1 & 0.1 \\
\hline Barium & $\mathrm{mg} / \mathrm{l}$ & 560 & 0.68 & - & - \\
\hline $\mathrm{TS}$ & $\mathrm{mg} / \mathrm{l}$ & 2016 & 226 & - & - \\
\hline TDS & $\mathrm{mg} / \mathrm{l}$ & 1100 & 208 & 2100 & 2100 \\
\hline TSS & $\mathrm{mg} / \mathrm{l}$ & 38 & 5 & - & - \\
\hline Turbidity & & 5 & 2.5 & - & - \\
\hline Chromium & $\mathrm{mg} / \mathrm{l}$ & 3.2 & 0.01 & 0.5 & 1 \\
\hline Cyanide & $\mathrm{mg} / 1$ & 0.6 & 0.009 & 0.1 & 0.2 \\
\hline Chloride & $\mathrm{mg} / \mathrm{l}$ & 27.5 & 6.58 & 600 & 600 \\
\hline Nitrate & $\mathrm{mg} / \mathrm{l}$ & - & - & 10 & 10 \\
\hline Color & & Black & Clear & - & - \\
\hline
\end{tabular}


This comparison shows that the parameters' value of the treated water is favorable enough to reuse it in other purpose. ACI and similar other industries can reuse it in various ways than just to leave it in the environment. We can offer the following ways to reuse the water treated out from the ETP in context of Bangladesh.

1. Irrigate the land located surrounding the industrial area.

2. Reuse for textile purpose; In Bangladesh there are lots of industries in textile sector. The textile industry is very water intensive [3]. Water is used for cleaning the raw material and for many flushing steps during the whole production [3]. Finishing raw fabrics is a basic textile industry operation. Water use varies with the type of fiber being produced and can range from 50 to $600 \mathrm{~m}^{3} \mathrm{t}^{1}$ [4]. This water demand in the surrounding textile industries of a pharmaceutical ETP can be supplied after treatment.

3. At present there are about 170 tanneries in Bangladesh, of them 114 are large and medium units (by local standards) [5]. The treated water can be used in this sector which may offer some savings in the use of pure water in this sector.

4. The water quality for a cooling tower is not high; it is possible to recycle cooling wastewater, reclaimed water from the effluent from other industries. This practice saves water charges for the plant and effluent discharge costs for treatment authorities. A saving of a $\$ 1$ million per year was reported by using $4000 \mathrm{~m}^{3} \mathrm{~d}$ 1 reclaimed water in the power station near Newcastle, Australia. [7] Water treated from pharmaceutical ETP can be proposed to use for this purpose in Bangladesh after some advanced treatment.

5. A very useful application of this treated water can be in the surrounding of the relevant industries; it can be used in washing the factory premise and watering the plants surrounding the industrial area.

\section{CONCLUSION}

The enzymes and bacteria used for anaerobic biological treatment are very expensive. New research should come up to find low cost enzymes. There is no relevant process for treating organic pollutants other than reverse osmosis to some extent. Incorporating reverse osmosis unit and molecular sieving is costly though, such plant can be recommended to be installed by WASA to treat water since they collect water from rivers, being all polluted with industrial \& municipal abuse. This water must be treated well before drinking. WASA can \& should install it \& afford by increasing tax which is now very nominal, $5.5 \mathrm{tk} / \mathrm{lit}$ when mineral water selling companies are selling it at $15 \mathrm{tk} / \mathrm{lit}$ with a profit almost 6 tk /L [8]. The selling of methane, produced from biological lagoon during treatment, can make some money for the industry but such unit causes $\mathrm{H}_{2} \mathrm{~S}$ emission. Future work is needed to find out a feasible solution to this shortcoming. It essentially needs work to be done to have cheaper and full proof way to organic effluent removal since industries, like pharmaceuticals, discharge lots of organic chemicals and without removing them the waste water ultimately can be treated up to "reuse" grade industrially or distilled at best, but not up to potable or drinking quality.

\section{ACKNOWLEDGEMENT}

The authors wish to acknowledge the contribution of Dr Md Iqbal Mahmud, Professor Emeritus, Department of Chemical Engineering, Bangladesh University of Engineering \& Technology, for his guidance to help complete the work properly. Acknowledgement also goes to Dr Mohidus Samad Khan, Post Doctoral Fellow, McGill University, for all his valuable suggestion and co operation.

\section{REFERENCES}

[1] Water Purification, Wikipedia.

[2] Commercial Report of ACI Pharmaceuticals, 2007.

[3] Water Reuse in the Textile Industry, http://www.lenntech.com/water_reuse_textile_indus try.htm

[4] A. Rossi, F. Malpei, L. Bonomo, R. Bianchi, Textile Waste Water Reuse in Northern Italy. Milan, Italy, 1999.

[5] Trierweiler, Gutterres, and Aquim et al, Assessment of Water Management in Tannaries: State of Rio Grande do Sul Case Study.

[6] Waste Water Recycling Treatment Solution. http://www.permionics.com/waste_treatment.htm

[7] Asano and Visvanathan, The Potential for Industrial Water Reuse.

[8] Banglapedia, National Encyclopedia of Bangladesh.

[9] Bangladesh Association of Pharmaceutical Industries,

http://www.pharmainfobd.com/pharma_organizatio ns/bapi.htm

[10] Bangladesh Environmenatal Conservation Rules 1997.

[11] Environ, Evaluation of Water Reuse Technologies for the Textile Industry, 2006.

[12] Metcalf and Eddy, Waste Water Engineering Treatment Disposal Reuse, 4 and 5 Edition, McGrae Hill, New York, 1995.

[13] Orch, Walter, Water Purification, McGraw Hill, New York, 1981.

[14] Khataruzaman, M., Clemett, Alexandra. Knapp, Jerry. Ahmed, Sumaia and Mashmood, A., Choosing an Effluent Treatment Plant, DFID, 2006.

[15] Haq, Azizul, and Chandraq Ganes, Pollutiing Industries in Bangladesh, 2002.

[16] Eckenfelder, M. Wesley, Industrial Water Pollution Control, $2^{\text {nd }}$ Edition, 1989.

[17] American Water Works Association, Water Treatment principles, ASA Publication, New York, (1984). 